\title{
Social value measurement in basketball clubs: is it possible?
}

\section{Xabier Mendizabal Leiñena, José Domingo García Merino}

ABSTRACT: In recent decades, sport has become one of the most important social activities in the Western world, showing an important capacity to attract people from different backgrounds. In this sense, basketball clubs do not pursue economic profit maximization, but instead they need to be analyzed according to their capacity of creating both social and economic value. In this regard, social accounting, as a tool that measures social effects, is also applicable to a basketball club.

For that end, in this paper we have applied part of a social accounting methodology, the SPOLY Methodology (Retolaza, San-Jose, \& Ruíz-Roqueñi, 2015), to two elite basketball clubs of the ACB League (Spanish First Division), in order to make further steps towards the future monetization of social value. For that purpose, in this paper we will identify different outputs and proxy-s corresponding to a range of specific social value variables established in the interviews with the different stakeholders that were identified in a standard stakeholder map for elite basketball clubs (Mendizabal et al., 2020).

Subsequently, 13 sports management experts, both lecturers and practitioners, have validated the list of specific social value outputs and proxy-s identified. The findings support the application of the SPOLY Methodology in basketball clubs, and the process of adaptation and validation carried out throughout the paper. The results also open a way towards the application of SPOLY Methodology in other top-flight sport organizations.

KEYWORDS: Stakeholder theory, Sport Clubs, Social Value, Indicators.

ECONLIT DESCRIPTORS: Z2, M2, Y1.

How to cite this article: MENDIZABAL, X. \& GARCÍA, J.D. (2021): "Social value measurement in basketball clubs: is it possible?", CIRIEC-España, Revista de Economía Pública, Social y Cooperativa, 101, 57-83. DOI: 10.7203/CIRIEC-E.101.18384.

Correspondence: Xabier Mendizabal Leiñena, University of Deusto (Spain), ECRI Research Group Ethics in Finance \& Social Value (Spain), xabier.mendizabal@deusto.es, ORCID: 0000-00019733-8048; José Domingo García Merino, University of the Basque Country UPV/EHU (Spain), ECRI Research Group Ethics in Finance \& Social Value (Spain), josedomingo.garcia@ehu.eus, ORCID: 0000-0003-3502-9893. 


\section{Resumen extendido}

\section{La medición del valor social en los clubes de baloncesto ¿es posible?}

\section{Objetivos}

Dentro del tercer sector, un sub-sector de gran relevancia por su impacto mediático y por los volúmenes de personas y recursos que mueven, son los clubes deportivos de elite, instituciones caracterizadas por un eminente carácter no lucrativo y social (Chaves Ávila, 2017). En el caso de nuestro objeto de estudio, los clubes de elite de baloncesto españoles de primera división (Liga ACB), a pesar de su estatus como entidades de no-lucro, su supervivencia está en entredicho por sus resultados económicos negativos las dos últimas décadas (Consejo Superior de Deportes, 2019). En consecuencia, la contabilidad social como área de conocimiento puede realizar una considerable aportación con objeto de reflejar la creación de valor holística de estas organizaciones a sus stakeholders (Lazkano \& San-Jose, 2020), en razón de algunas particularidades de estas entidades como la cooperación entre distintos equipos para organizar competiciones (Holt, 2009), la necesidad de establecer relaciones con stakeholders como entidades sociales y personas aficionadas (Morrow, 2013), y la trascendencia del activismo de distintos stakeholders en la toma de decisiones de estas organizaciones (Biscaia, et al., 2019).

Por ello, el objetivo de este artículo se basa en proponer un modelo de contabilidad social que pueda ser aplicado a los clubes deportivos de élite, con objeto de obtener una visión más global de la creación de valor a los stakeholders llevada a cabo por estas organizaciones, y abrir un camino que ayude a estas organizaciones a complementar su información financiera con otra información que tenga en cuenta el valor generado a sus distintos stakeholders.

\section{Diseño/ metodología/ aplicación}

Para cumplir los anteriores objetivos, planteamos una adaptación de la metodología SPOLY (Retolaza, San-Jose, \& Ruíz-Roqueñi, 2015), a la realidad de la gestión deportiva, y más concretamente a los clubes de baloncesto de élite. La metodología SPOLY para el cálculo y cuantificación del valor social integra tanto el valor social de mercado como el valor social de no mercado o específico, entendiendo el valor social específico como aquel valor no reflejado a través de una transacción de mercado.

Este proceso de adaptación incluirá tanto a los stakeholders identificados en el mapa de stakeholders para los clubes de élite de baloncesto, así como sus percepciones de valor acerca de la actividad de estas organizaciones (Mendizabal, San-Jose, \& Garcia-Merino, 2020). En consecuencia, se procederá a la identificación de distintas métricas de valor social específico, 
en forma de outputs y proxy-s, que permitan la monetización del valor social de no mercado. Para que estas métricas tengan un grado de aceptación el cual les permita ser utilizados como referencia, resulta clave su validación. Para ello, se ha presentado el anterior listado de outputs y proxy-s para su refrendo a distintos expertos en la gestión deportiva, tanto académicos como profesionales del sector. El proceso mencionado será aplicado en dos clubes de élite de baloncesto de la Liga ACB, ambos de características distintas, los cuales han sido elegidos para reflejar la importancia de las experiencias, identidades y expectativas de los diferentes stakeholders de cada club, en concordancia con otros estudios de gestión deportiva (Giulianotti, 2005).

\section{Resultados / Limitaciones a la investigación / implicaciones}

Se ha obtenido una batería tanto los outputs y proxy-s que permiten recoger el valor social específico generado por estas organizaciones, de acuerdo con la opinión de las personas expertas consultadas. De acuerdo con una escala Likert del 1 al 5, la gran mayoría de outputs y proxy-s propuestos a priori (19 en cada caso), obtuvieron una valoración media superior al 3,50 (la media mínima para la validación de la magnitud en cuestión). Los outputs "actividades con asociaciones culturales y sociales", "actividades de formación con niñas y niños durante la temporada" y "valor emocional" han obtenido los mejores resultados, mientras que los proxy-s "descuento en $€$ aplicado a los tickets", "valor en $€$ de la donación de material deportivo" y "precio no cobrado a niñas y niños en dificultad por participar en actividades de baloncesto" obtuvieron los mejores resultados.

En relación a la principal implicación que presentan los resultados previos, debemos de enfatizar la posibilidad de mostrar un valor social específico en las organizaciones analizadas, el cual va más allá del valor social de mercado creado por estas organizaciones, el cual puede ser medido y monetizado, y que presenta una aceptación amplia. Su aplicación permite mostrar la existencia de un valor de carácter holístico creado por las organizaciones a sus stakeholders, más allá del valor económico generado a sus accionistas.

Con respecto a las principales limitaciones, cabe destacar el hecho de no haber encontrado indicadores y proxy-s adecuados para llevar a cabo la futura monetización del valor emocional, identificado como una fuente de valor importante por los expertos en gestión deportiva.

\section{Conclusiones prácticas y valor original}

Como instituciones sociales con una importante orientación a sus stakeholders, tal y como determina su misión, un análisis en base a la contabilidad financiera es insuficiente, por ello la principal contribución de este trabajo es el desarrollo de una herramienta que puede ser aplicada e implementada en los clubes de baloncesto de élite, el cual les permita mostrar el valor generado.

A este respecto, el esfuerzo de adaptación y validación de la metodología permite disponer de un conjunto de outputs y proxy-s validados por 13 expertos de gestión deportiva. Este 
aspecto hace que los resultados obtenidos sean más robustos y significativos tanto para la academia como para la gestión de los clubes de élite.

La medición de la creación de valor social por un club deportivo de élite dará a los gestores un nuevo instrumento de gestión. En organizaciones sin ánimo de lucro como los clubes deportivos, dado que el resultado financiero no es un referente es necesario desarrollar indicadores alternativos para evaluar la actividad de estas organizaciones de acuerdo a su capacidad para crear valor a sus stakeholders. El conocimiento y medición de las distintas dimensiones de valor social que un club de baloncesto de élite crea a sus stakeholders, como las comunidades y agentes sociales, clientes y usuarios, administraciones públicas, medios, proveedores, empleados y competiciones deportivas, aparte de los accionistas, representará el primer paso para mejorar la gestión de estas organizaciones. Estos resultados abren una vía para el análisis de valor creado por estas organizaciones desde una perspectiva holística y no exclusivamente financiera.

Al mismo tiempo, los resultados serán de interés para la administración pública a la hora de valorar la conveniencia de apoyar o no la política de los clubes en su jurisdicción. La capacidad de estas organizaciones para crear valor a sus stakeholders puede justificar la financiación a sus organizaciones, teniendo en cuenta que crean un importante valor social a sus stakeholders.

Palabras clave: Teoría de los Stakeholders, Clubes deportivos, Valor Social, Indicadores. 


\section{Introduction}

In recent decades, the conception about businesses as generators of purely economic value has been modified, in favor of a more holistic approach that considers them as economic social systems that carry out their activities within a social system with which they interact (Harrison et al., 2010). This leads us to a change in the information systems. Traditional information systems are based on financial accounting, considered as an appropriate mechanism to transmit information about the value created to a business' shareholders. Hence, the previous change of perspective about businesses' role has led to the advent of a new reporting system, social accounting. In this regard, social accounting relates to the social and environmental effects that are not reflected in traditional financial accounting practice. More precisely, social accounting could be defined as "the process of communicating the social and environmental effects of organizations' economic actions to particular interest groups within societies and to societies at large" (Mathews, 1997, p. 483). However, although social accounting has been strongly developed in sectors like non-profit ventures (Nicholls, 2009), there is still a long way to go before an standardization of social accounting methodologies is achieved.

One of the sub-sectors where social accounting finds ground for development is in elite sport organizations. These organizations, in conjunction with sporting federations and associations, belong to the sporting third sector and are characterized by their non-profit status (notably in Europe) (Andreff, 2011; Chaves Ávila, 2017). Other characteristics include the cooperation between competing clubs to deliver the main product (a sports competition) (Holt, 2009), the high importance of relationships with stakeholders like local communities and fans (Brown et al., 2010), and the high intensity of stakeholder activism (Biscaia et al., 2019). In this sense, our focus of interest will be on elite basketball clubs, due to their important role as third sector organizations and their popularity and social significance in the Spanish context (Pujol Pinto, 2019).

However, ever since the 1990s, the increasing orientation of elite sport clubs towards the creation of economic value has been gaining more and more attention (Conn, 1997), owing both to the legal changes that have brought a bigger convergence in legal and financial structures between for-profit businesses and non-profit sport clubs in Europe and Spain (Barajas Alonso \& Rodríguez Guerrero, 2009), and the increasing turnover and media attention that elite sport competitions and their clubs enjoy (King, 1997; Morrow, 2013). Nonetheless, the particular nature of these organizations as entities that have originally a non-profit status makes the consideration of sport clubs as businesses oriented to shareholder-value maximization quite problematic (Morrow, 2000). In the case of Spanish top-flight basketball, and more precisely its main competition, the ACB League, clubs' global deficit has risen from 22,6 million to 81,2 million $€$ from 2000 to 2018 , considering that never in this period has the competition achieved to break even (Consejo Superior de Deportes, 2019).

However, despite the previous vulnerable financial situation, the majority of clubs from this competition keep on competing and surviving at the elite. In this respect, the usage of financial magnitudes per se is not capable of visualizing and demonstrating the real picture of value cre- 
ation of elite basketball clubs to their stakeholders, given that these financial magnitudes only reflect the evolution of shareholder value and the wealth of the company (Morrow, 2013). For this reason, we theorize that there could be other elements in the activity of elite basketball clubs that lead to stakeholder value creation and make it possible for these organizations to survive in spite of the previous financial difficulties, considering their social orientation and non-profit status (Kesenne, 2000; Martínez-Lemos, 2015). Although literature has focused on the analysis of the main financial magnitudes of elite sport clubs, placing increasing emphasis on their shareholder value creation (Barajas Alonso, 2004; Barajas Alonso \& Rodríguez Guerrero, 2009), we advocate a multi-stakeholder perspective that analyzes the different perceptions of stakeholders relating the holistic social value created by the company (Retolaza Ávalos et al., 2015). In this regard, financial complications are only associated to part of the value that shareholders receive, but shareholders (as well as other stakeholders) might perceive other value elements in the form of intangible aspects, like emotional connection, that can be crucial in the value creation cycle of sport clubs (Coates et al., 2017). In this sense, emotional value would represent an important value in the eyes of different actors that support the club, like fans and shareholders (Morrow, 2000).

Considering the potential of sport to unite communities and contribute to social cohesion (Smith \& Westerbeek, 2007), literature has also studied the celebration of generalistic sport events like the Olympic Games or World Championships, analyzing the possible effects in terms of attraction of tourism, civic pride or additional consumption in the hosting cities and communities (Agha \& Taks, 2018; Coates \& Szymanski, 2015). However, although sport events represent an interesting research field, they do not represent an object of interest in this research, given the differences between events organized by sport clubs and generalistic sport events. Among them, we can find their length (clubs play throughout the year while generalistic events take place in a short time frame like few weeks), the fact that public to sport events is more local while generalistic events attract a wider public from different spots, and the fact that there exists a stronger emotional bonding between the public and sport clubs in their events than in more generalistic events (Barajas Alonso, 2004; Liu, 2016).

From our perspective, social accounting can be really meaningful in elite sport clubs, since they, unlike other non-sport organizations, are deeply embedded in society, creating a strong pressure for them to relate to their stakeholders, since these clubs are considered to be important influencers culturally and socially (Babiak \& Wolfe, 2009). However, for social accounting to be relevant it is necessary that it is accepted in the first place. While those systems based on financial accounting have been recognized by social and economic agents since they reflect market transactions (Nicholls, 2009), the problem with social accounting is that not all the operations it reflects are market operations (Nicholls, 2009). As Gray (2001) points out, for a social accounting system to progress, it is necessary to have a reliable and trustworthy model. It is precisely in this field that the obtained results are more discouraging (Gray, 2001). In this regard, one of the most important aspects is that $71 \%$ of the respondents of a survey conducted by the GIIN and J.P.Morgan (Saltuk et al., 2014) consider progress in the standardization of metrics to be very important (Saltuk et al., 2014). 
At the same time, it is necessary to consider social accounting as a tool that can help adressing ethical and intellectual aspects that are important for the accounting discipline today (Gray et al., 1994). The progress of social accounting will be possible as long as it builds up an identity of its own, representing a useful tool for the organizations that will help improving the quality of the information, extending the utility of the information it provides to other agents than shareholders and creditors (Rasche \& Esser, 2006).

Hence, our objective is to put forward a social accounting model that could be applied to the particularities of elite sport organizations. For that to happen, we will apply an already developed methodology, the SPOLY Methodology (Retolaza Ávalos et al., 2015), based on stakeholder theory, and we will carry out a process of adaptation of this methodology to the particularities of elite basketball clubs. The SPOLY Methodology for the determination of social value distinguishes between market social value and non-market or specific social value, understanding specific social value as the non-economic value that the organization distributes among its several interest groups (Retolaza Ávalos et al., 2015). Hence, it is necessary to make bigger efforts to measure the non-market social value, as it will not be reflected by way of a market transaction like market social value is.

The process of adaptation will include the specific stakeholders of these organizations as well as the perceptions of these stakeholders about the value they receive from these organizations. Therefore, a number of metrics that will reflect the social value created by elite basketball clubs to their stakeholders identified in a standard stakeholder map will be put forward. These metrics will be validated afterwards by a group of experts in sports management. The aforementioned process will be applied to two basketball clubs from the ACB League (Spanish basketball First Division). Two clubs with very different characteristics were chosen to ensure that a wide range of stakeholder identities, experiences and expectations relative to the social value perceived from the activity of these clubs were canvassed (Giulianotti, 2005).

This contribution aims to represent a first step in the measurement of the holistic value created by elite sport organizations. The raison d'être of these clubs precludes them from the assessment of their activity only on the basis of their financial information (Morrow, 2013), and taking into account that alternative indicators have not been systematically proposed for this purpose, we think it necessary to develop alternative tools that measure and quantify the social value creation to stakeholders undertaken by these organizations.

The article will be structured as follows: After this introduction, the process of partial implementation of the SPOLY Methodology will get started. Firstly, the steps of the SPOLY Methodology will be explained, with a particular attention on the steps that will be treated in this analysis. Afterwards, the identification of the specific social value variables will be dealt with. By establishing the specific social value variables, we will move on to the decision about the outputs and proxy-s that will be representative of the specific social value variables identified and the validation of these outputs and proxy-s by experts of the sports management field, both from the academic and professional field. The paper will end up with a final section of conclusions. 


\section{Social impact measurement methodologies}

The identification of social impact measurement methodologies is on the rise, and Olsen and Galimidi (2008) identified up to 25 different methodologies. As Grieco, Michelini and Iasevoli (2015) said "there are many reasons why a large number and variety of methods are available, the first of which being to facilitate an organization by providing methods that suit their customized business models" (p. 1178). They go on to mention that methods are also designed to cater for the needs of particular stakeholders (Grieco et al., 2015). Faiz (2016) interviewed 15 different experts about the main challenges that a social value measurement presents, and two main challenges were identified: communication and accountability. SPOLY Methodology tries to adress these issues in the following way (Retolaza Ávalos et al., 2015):

- It reflects social value in monetary terms. One of the advantages of choosing money as a value unit is that it facilitates the interpretation of results and the comparability among them. This methodology reflects social value coming both from market and non-market dimensions. The first part is based on traditional financial accounting data, while non-market social value requires the establishment of indicators that will permit the estimation of that value created about which there is not a direct market transaction involved.

- This methodology is based on stakeholder theory. Moreover, this methodology will take into account the stakeholders with which the organization interacts, and calculates both the specific social value created to each stakeholder and an integrated social value.

Hence, the process followed in SPOLY Methodology can be summed up in five different steps (Retolaza Ávalos et al., 2015):

1) Implication of the organization: Active participation of stakeholders is essential for the social audit to be effective, especially when management occupies a weaker bargaining position, notably with professional stakeholders (Greenwood, \& Kamoche, 2013). We got in touch with both MT1 and MT2. We sent them the necessary information, and both organizations' representatives told us their interest to set up a presentation meeting. Both meetings were successful, and after all our explanations both organizations showed their interest to participate.

2) Stakeholder identification: Once the timetable was set and the working team was identified, the next phase consisted on the elaboration of the stakeholder map of the organization. As we have mentioned an adaptation process becomes necessary. In this sense, Mendizabal et al. (2020) specify the main stakeholders of elite basketball clubs, as shown in Figure 1 below. 


\section{Figure 1. Stakeholder map for elite basketball clubs}

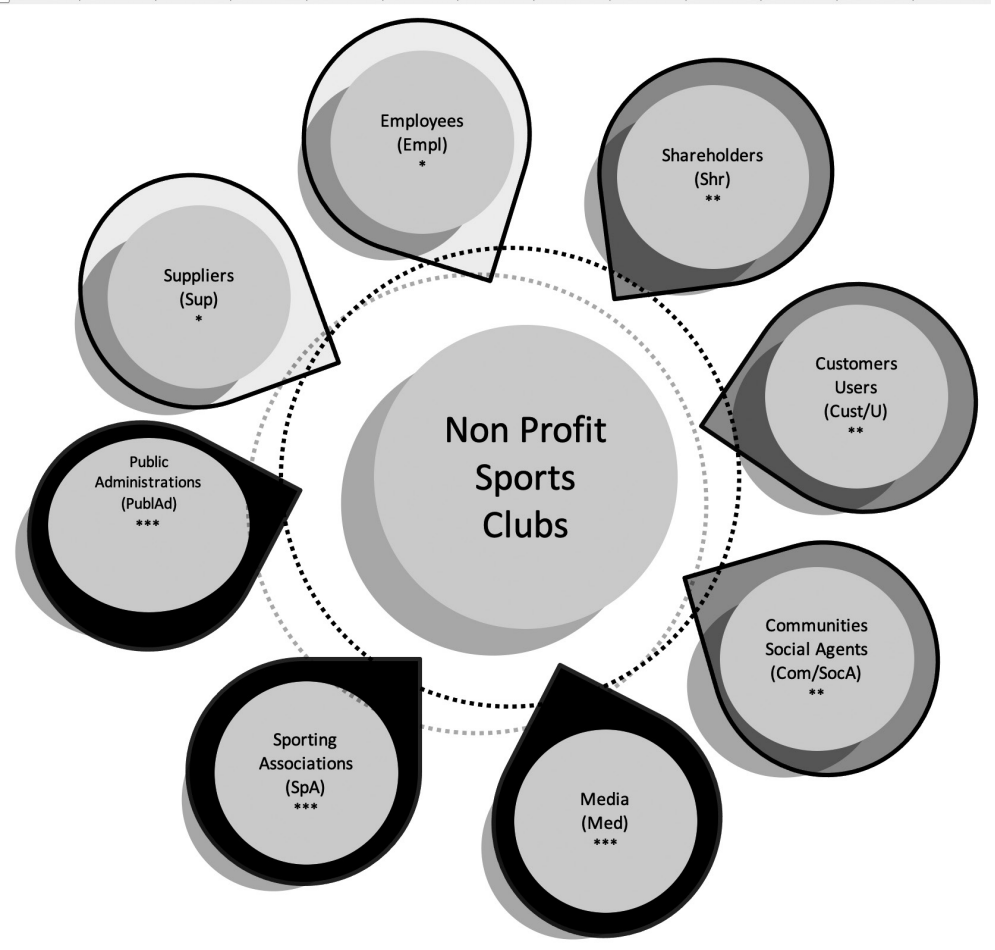

Source: Mendizabal et al., 2020, p. 372.

The eight stakeholders identified are differentiated by three signs: one asterisk (stakeholders who are similar to the stakeholders of non-sport-NsP- companies: suppliers and employees), two asterisks (stakeholders who are both similar to and distinct from the stakeholders of NsP companies: shareholders, customers and users and communities and social agents) and three asterisks (stakeholders who do not have any similarity with the stakeholders of NsP companies: media, sporting associations and public administrations).

3) Identification of specific social value variables: At the same time, Mendizabal et al. (2020) established the main social value dimensions identified by each stakeholder in the interviews with them. As it can be observed in Figure 2, an elite basketball club can create value by means of four different dimensions. 


\section{Figure 2. Dimensions of value created by clubs to their different stakeholders}

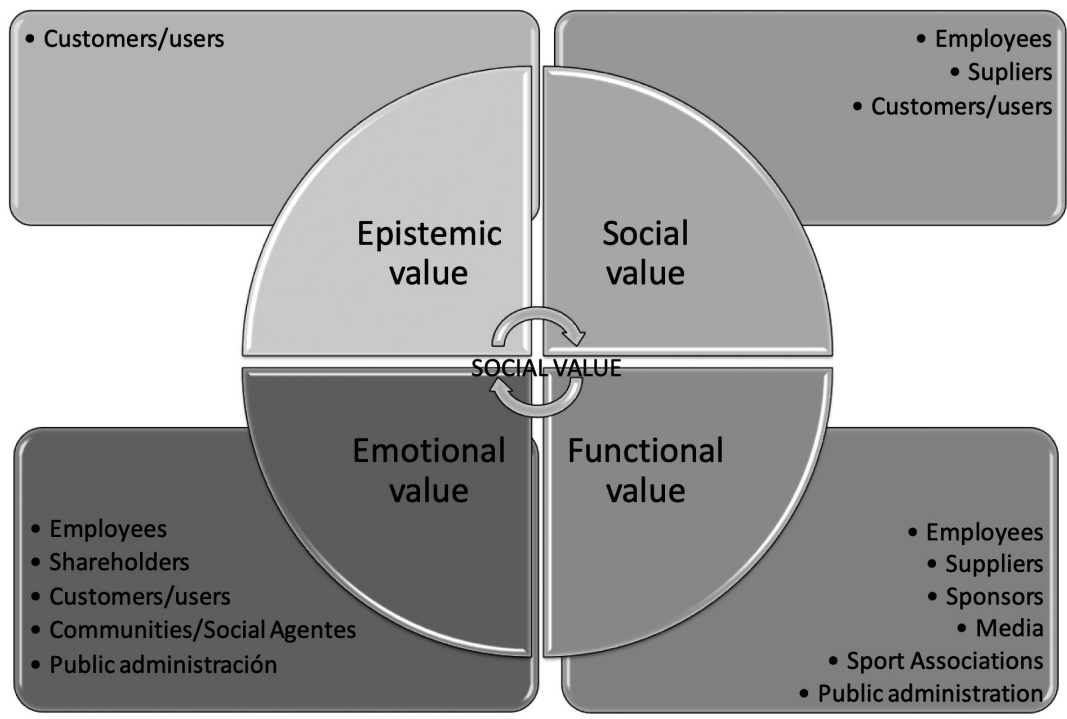

Source: Adapted from Mendizabal et al., 2020.

Social value or relational value, in this context, refers to the utility created by the organization to its stakeholders as the activity of the club provides individuals with the opportunity to connect with other relevant social groups, thereby creating bigger social bonding and enhanced peer group acceptance for stakeholders (Kunkel et al., 2017). For the rest of the paper, the term social value would refer to the specific social value, understood as the the non-economic value that the organization distributes among its several interest groups (Retolaza Ávalos et al., 2015). Emotional value represents the utility derived from the feelings or affective states that consuming a certain product or service generates, in this case the sports team (Kunkel et al., 2017). Emotional value, as well as functional value, is present in the majority of stakeholders, being an important element to attract them to the club (Coates et al., 2017). Concerning epistemic value, we could define it as the utility derived from the capacity of a certain organization's activities (in this case, the basketball club) to arouse curiosity, provide novelty and satisfy a desire for knowledge (Kunkel et al., 2017). Functional value represents the utility derived from the perceived quality and expected performance of sport team games (Kunkel et al., 2017).

Hence, the main challenge in this paper will be to identify social value variables that will permit the future monetization of the specific social value created by these organizations to their stakeholders. This is one of the most complex stages of the process, consisting of the 
redefinition of the specific social value variables and the reformulation of the specific social value variables oriented to indicators that could be linked to outputs measurable by the organization, and that could include proxy-s that will make it possible the monetary valuation of those outputs.

4) Identification of outputs and proxy-s linked to specific social value variables: Once the specific social value variables have been obtained, it is necessary to identify the outputs created by the organization that correspond to the variables, as well as the proxy-s (monetary value of each output unit from each specific social value variable) that will allow its monetization.

5) Monetization of the variables in question. Normally there will not be an unique proxy, but different proxy-s instead, and sometimes it will be necessary to be prudent to choose the most adequate proxy in order not to overrate the monetary value that can be allocated to each specific social value variable.

This paper will focus on the third and specially the fourth step of SPOLY Methodology.

\section{Identification of Specific Social Value Variables}

SPOLY Methodology reflects not only the social value generated through economic activity, but also the specific social value generated to the different stakeholders without a market transaction. The calculation of the former value dimension does not present any complexity since it is already reflected in financial accounting. The calculation of the latter value dimension remains absent in financial statements and has to be monetized with the help of indicators and proxies.

Firstly, the specific social value variables will be established taking into account the interviews with stakeholders' representatives to validate the stakeholder map, and secondly the process of determination of the outputs and proxy-s and their validation by experts will be established. By setting the specific social value variables, we will move on to one of the most critical steps, the decision about the outputs and proxy-s that represent the social value variables identified and the validation of these outputs and proxy-s by sports management experts. The identification of the main social value variables created by clubs and the subsequent validation of the outputs and proxy-s by experts will validate the applicability of SPOLY methodology in these organizations, considering their specific value creation context. 


\subsection{Identification of Specific Social Value Variables of non-market social value}

The first part of the process starts with the identification of value-creating activities for stakeholders. This process has two differentiated steps: the first is the analytic, by adopting grounded theory and phenomenological principles (Smith \& Osborn, 2003). In the second phase, of synthetic character, the activities with strong resemblances are integrated and redefined orientating them towards outputs about which both clubs possess data (or could obtain data in the future) (Retolaza Ávalos et al., 2015).

Then, we have taken as a reference both the stakeholder map from Figure 1, and the main dimensions of value identified in Figure 2 by way of the interviews conducted with stakeholders' representatives. In this regard, we have used a "purposeful sampling" approach to select the clubs analyzed (Palinkas et al., 2015) while also using an extreme or deviant case strategy, selecting unusual cases rich in information (Draucker et al., 2007). MT1 is a top team with a big budget and success in national and international championships, whereas MT2 is a team with little budget and success. The stakeholders' representatives were asked about the clubs' actions that are creating specific social value according to them. Synonymous expressions have been integrated. The main activities identified are the following: 


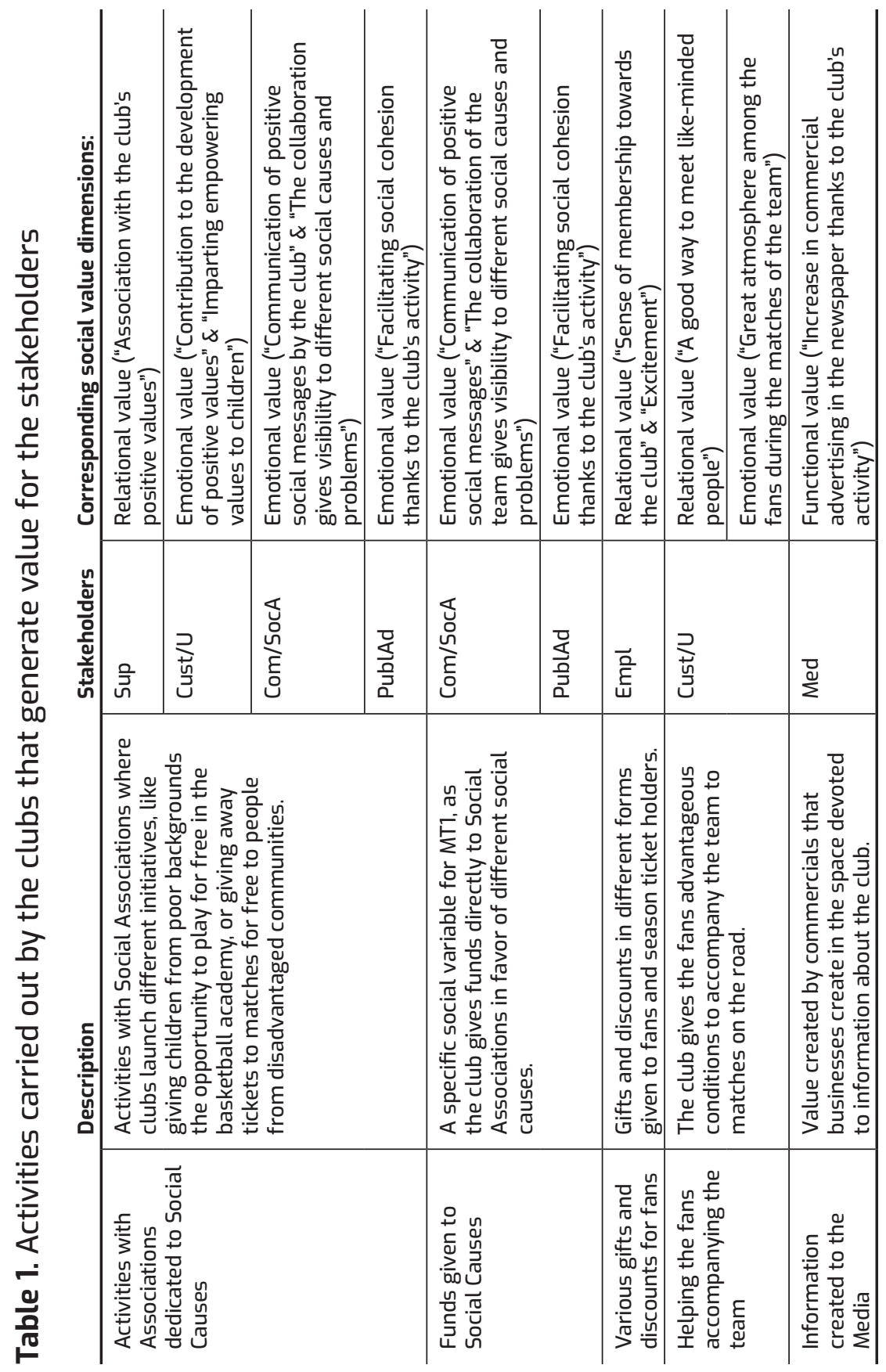




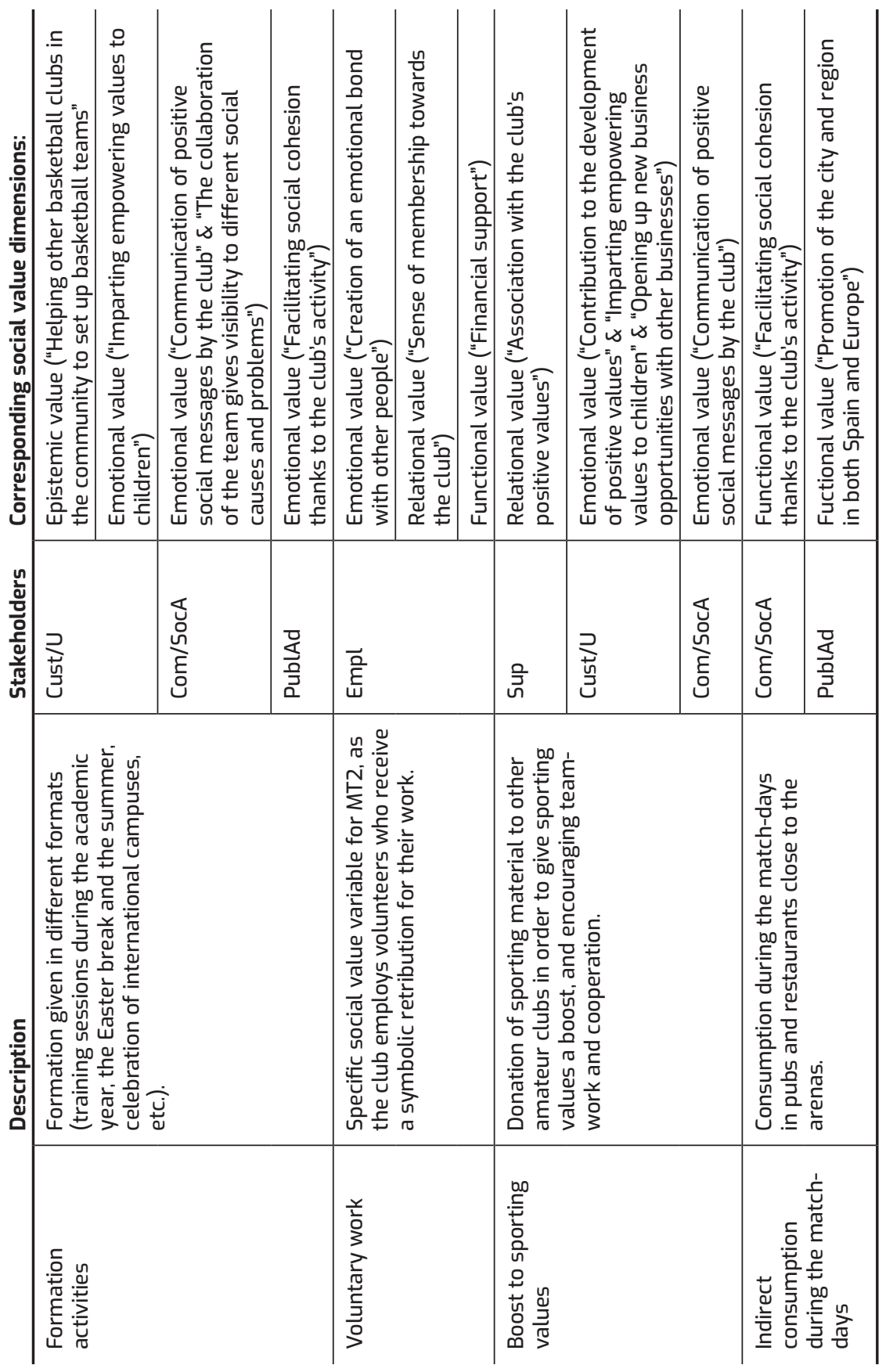


The reduction of social value variables will simplify the process and make it easier to build specific social value indicators afterwards. We consider that the "Activities with Associations dedicated to Social Causes" and "Funds given to Social Causes" can be grouped as the tipology of indicators that are included in them will be similar, as it is the case in both "Various gifts and discounts for fans" and "Helping the fans accompanying the team to matches on the road".

It should be noted that each value dimension can be identified in two or more value variables at the same time. As it has been seen, the majority of value variables identified are common for both clubs. Nonetheless, there are particular value variables for each club, like "Information created to the Media" in MT1 and "Value created to the volunteers of the club" in MT2 that are particular for each organization. Hence, the homogeneity of social value variables will make it easier to conduct a monetization of social value in both clubs in the future.

Taking into account the previously identified non-market social value variables, by means of the cooperation with the clubs analyzed we went on to transform these magnitudes into definitive social value variables oriented to indicators that could be afterwards linked to outputs that are measurable and that could be quantified in monetary terms by proxy-s.

After drawing up this list of value variables, they were given the approval by the contacted managers of both clubs, as a previous and necessary step for the determination of the corresponding indicators and proxy-s. The value variables will be presented in the following table. The value variables that have a $\left({ }^{*}\right)$ sign are exclusive to one of the teams:

Table 2. Social value variables oriented to indicators in MT1 and MT2

\begin{tabular}{|c|c|c|}
\hline Number & $\begin{array}{l}\text { Social value variables oriented to indicators } \\
\text { in MT1 }\end{array}$ & $\begin{array}{l}\text { Social value variables oriented } \\
\text { to indicators in MT2 }\end{array}$ \\
\hline 1 & \multicolumn{2}{|l|}{ Activities with social and cultural associations } \\
\hline 2 & \multicolumn{2}{|l|}{ Gifts and discounts for season ticket-holders } \\
\hline 3 & \multicolumn{2}{|l|}{ Formation activities with children and young people } \\
\hline 4 & Information created to the Media ( $\left.{ }^{*}\right)$ & \\
\hline 5 & & Value created to volunteers $\left({ }^{*}\right)$ \\
\hline 6 & \multicolumn{2}{|l|}{ Donation of sporting material } \\
\hline 7 & \multicolumn{2}{|l|}{ Induced consumption in pubs and restaurants } \\
\hline
\end{tabular}

Source: Own elaboration. 
As it can be seen, the majority of social value variables are similar in both teams. However, the variables "information created to the media" in MT1 and "value created to volunteers" in MT2 are particular to each club.

\subsection{Identification of Outputs and Proxy-s from Specific Social Value Variables}

Afterwards, a brainstorming process started when the author checked the data from the interviews and the clubs' relevant documentation. This process helped identifying the outputs and proxy-s and their algorithms that are used to calculate the specific social value created to the stakeholders by each club. The output is the result obtained by the organization in relation to the indicators identified in each variable. The result of the output should refer to data that the organization has. Proxy-s are those magnitudes that allow the quantification of outputs. Normally, there is no single proxy, but several. When choosing the most suitable proxy, the simplest method involves choosing the proxy that most resembles the generated output. The process is similar to the fair value applied in traditional accounting. After identifying the algorithm (a multiplication), a value is determined for the proxy and a total monetary value to each variable is calculated (Lazkano de Anta \& San-Jose Ruiz de Aguirre, 2020). The specific social value outputs, proxy-s and algorithms for MT1 and MT2 are shown next in Table 3.

\subsection{Validation of Outputs and Proxy-s by Experts}

Once the specific social value outputs and proxy-s are determined, we will proceed to validate them on the basis of the opinions of experts from the sports management field. Our procedure of validation consist of sending the outputs and proxy-s to different sports management experts ( 7 from the academia and 6 professionals from sports management). We asked them whether they thought that a elite basketball club could create social value or not with each output or proxy. By a Likert scale, respondents had to express whether they completely disagreed (choosing 1) or completely agreed (choosing 5) with the outputs and proxy-s established for each value variable. The assumption was that the bigger the number chosen by the respondents, the more agreement they showed towards that output or proxy. In Table 4 , the job position of each respondent is explained: 


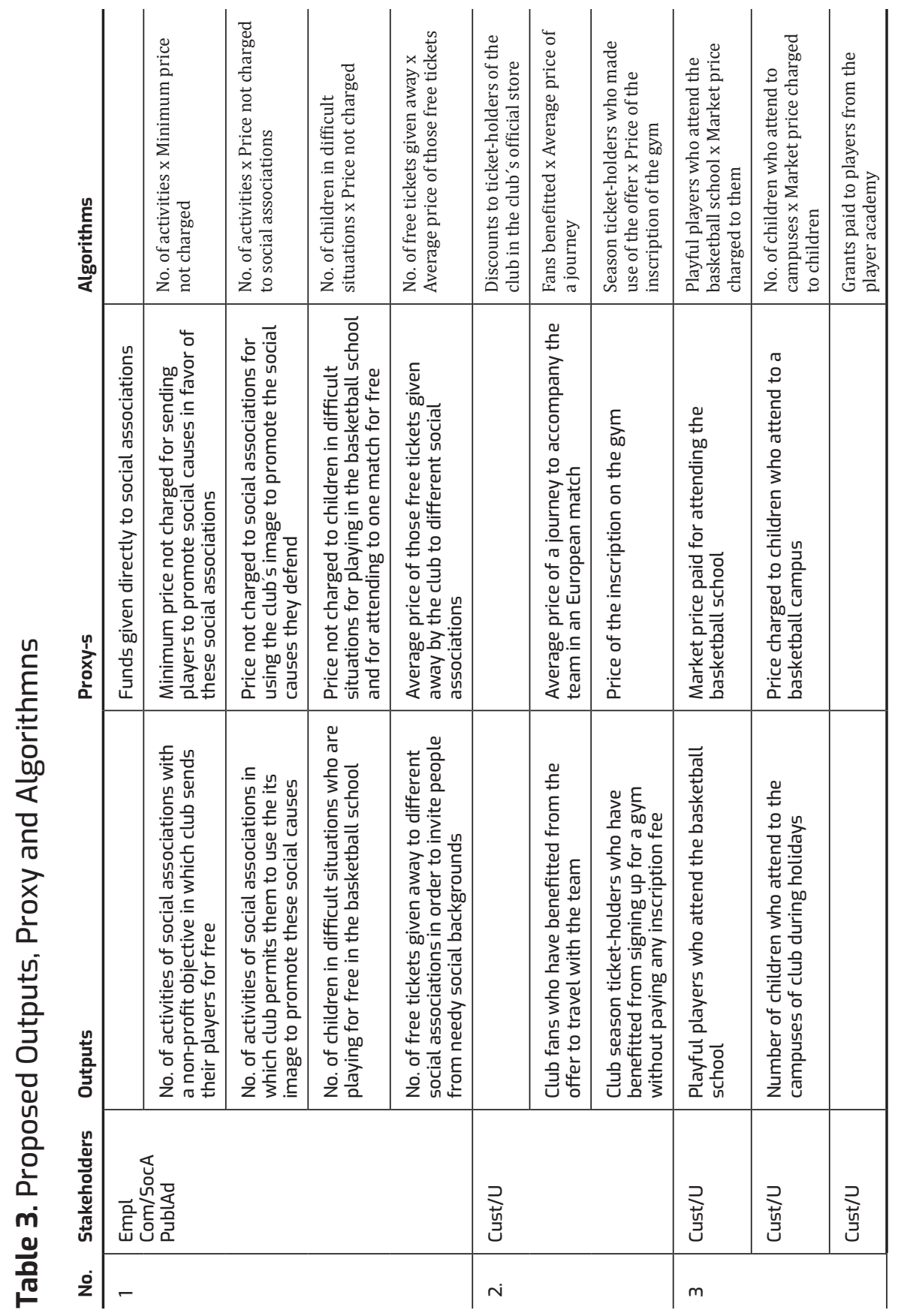




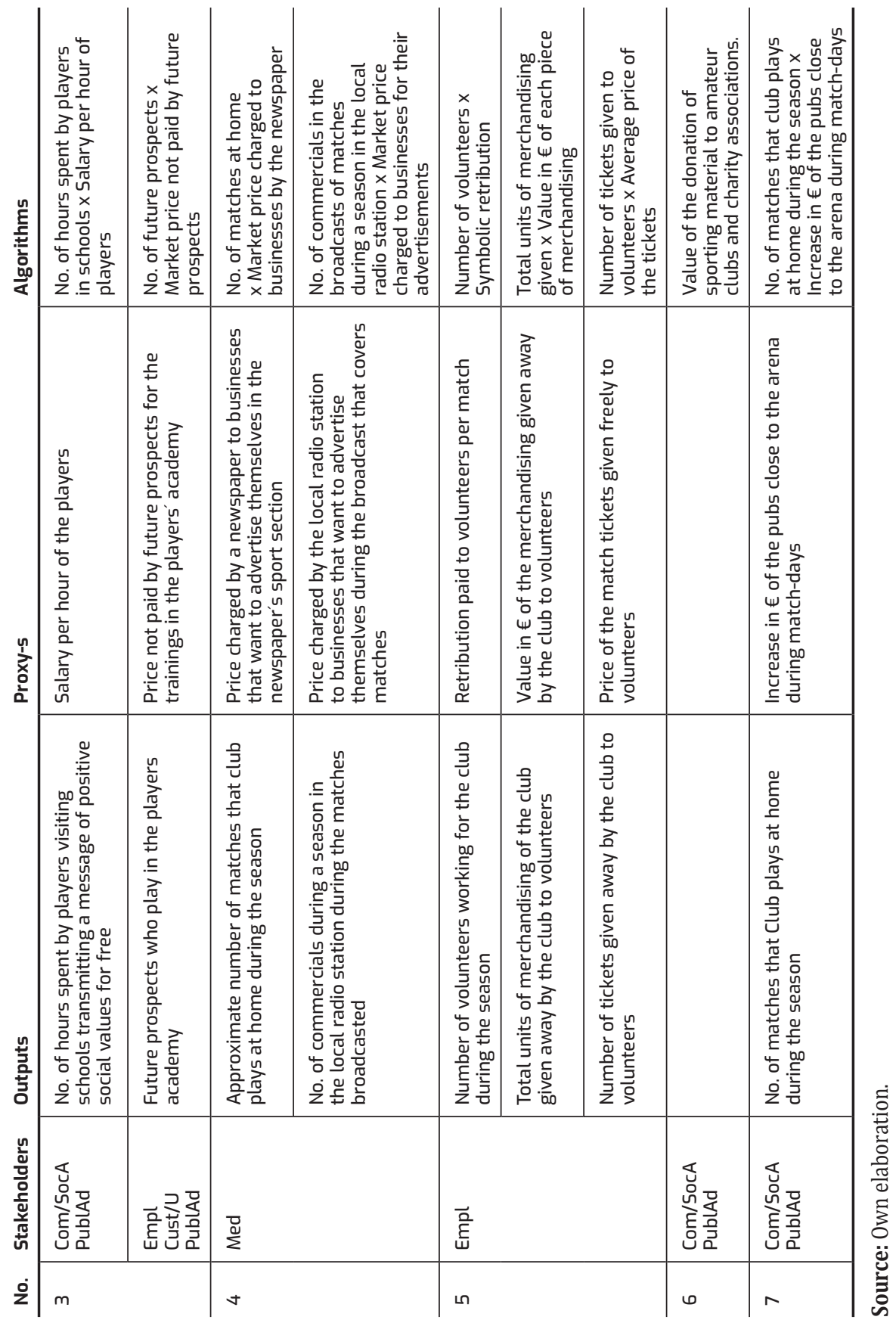




\section{Table 4. Description of respondents of the process of validation of outputs and proxy-s of specific social value}

\begin{tabular}{l|l} 
Respondent & Position \\
\hline Respondent 1 (R1) & $\begin{array}{l}\text { Lecturer at the University of the Basque Country UPV/EHU (Basque } \\
\text { Country, Spain) in the Sport Management Master. }\end{array}$ \\
\hline R2 & $\begin{array}{l}\text { Lecturer at the University of the Basque Country UPV/EHU (Basque } \\
\text { Country, Spain) in the Sport Management Master. }\end{array}$ \\
\hline R3 & $\begin{array}{l}\text { Lecturer at the University of La Laguna ULL (Canary Islands, Spain) in } \\
\text { Applied Economics and researcher on Sports Management issues. }\end{array}$ \\
\hline R4 & $\begin{array}{l}\text { Lecturer at the University of Pompeu Fabra (Catalonia, Spain) on Sports } \\
\text { Management. }\end{array}$ \\
\hline R5 & $\begin{array}{l}\text { Lecturer at Coventry University (United Kingdom) on Sports } \\
\text { Management. }\end{array}$ \\
\hline R6 & Lecturer at the University of Vigo (Galicia, Spain) on Sports Management. \\
\hline R7 & $\begin{array}{l}\text { Lecturer at the University of Oviedo (Oviedo, Spain) in Sports } \\
\text { Management. }\end{array}$ \\
\hline R8 & Former general manager of a team of the ACB League. \\
\hline R9 & Former president of a team that played in the ACB League. \\
\hline R10 & General manager of a team currently participating in the ACB League. \\
\hline R11 & Director of the financial department of a team from the ACB League. \\
\hline R12 & CEO of a team currently participating in the ACB League. \\
\hline R13 & Member of the advisory board of a team from in the ACB League. \\
\hline
\end{tabular}

Source: Own elaboration.

The criteria employed to consider an output or proxy as directly valid was that the combined mean should at least tally a result of 3,50 or higher, whereas a result between 3,00 and 3,49 was subject to a revision and passed if no better output or proxy was proposed by respondents. Finally, if an output or proxy tallied a mean below 3,00 then it was subject to a major revision and considered to be eliminated if no alternative output or proxy was found for the process of quantification. The answer from the respondents to each of the indicators is shown in the Table A1 in the Annex. Regarding the indicators, the majority of them have obtained a score bigger than 3,50, leading to their direct validation. Those indicators from the social value variables "Activities with cultural and social associations", "Formation activities to children during the season" and "Emotional value created" have got the best marks. The indicator "Children in a difficult situation that have taken part for free in the clubs' basketball school" got a mean of 4,85, with all experts giving it a mark no lower than 4 . R1 remarked that 
"this indicator is very adequate, but there should be a tracking of the well-being of the children by visiting them at their homes, by inviting them to different events, etc." Concerning the "Formation activities to children during the season", the indicator with a highest mark is "number of children that attend to the basketball school of the club during the season". R10 adds that "this is one of the main cornerstones of our activity." As regards the emotional value, the mark is really high: 4,78. R1 tells that "this is an intangible value but very important for fans."

On the contrary, the indicators from "Gifts and discounts to fans during the season" obtain a mean worth 3,15, 3,08 and 3,31 respectively, meaning that they will be subject to a revision. In the case of "Official products sold at a discount during the season" R7 answered that "it seems more related to a business activity than to the creation of social value." The same concerns are raised in indicators "season ticket-holders benefitted by the discounts in other commercial establishments thanks to the agreements of the club" and "Fans that have enjoyed special discounts when accompanying the team to matches on the road". R1 argues "the trip should be paid to those fans that show a minimum percentage of attendance to the matches at home." These remarks show concern that clubs could use discounts only for an economic gain. However, when asking the respondents about alternative indicators they did not come up with any alternative. Therefore, we revisited the interviews to the fans of both clubs, and we found that one fan interviewed highlighted: "we as the main fan group were relocated to better seats in the arena by the club as a way to recognize our effort as fans. We are aware that they are losing money because they have offered us the opportunity to occupy those seats at a discount." Hence, we will keep the previous two indicators, given that the fans have confirmed that the club was taking a financial loss to give them the opportunity to enjoy basketball.

"Generation of advertisements in those spaces dedicated to the clubs' information in the media", for its part, got a mean of 3,25 . One criticism was "this is more a commercial value than a social value" (R4). They did not propose any alternative indicator, we found that the owner of a local newspaper told us "if my newspaper covers the information about the club then the more likely we will get to attract more readers and advertisers." Hence, local media is interested in the club's activity. Therefore, we will keep the indicator. The indicator "Number of pubs and restaurants close to the clubs' arenas that enjoy an increase in income during match-days" was also questionned. The mean is 3,31. One of the arguments was "I see it as a good economic contribution for some businesses, but is this really a social value?" (R10). Therefore, we asked the owners of two pubs close to MT1's arena, and they confirmed that fans go there on matchdays, leading to an increase of the pubs' income, so we chose to keep this indicator. Having analyzed the experts view about the indicators, in Table A2 from the Anex the answers from the experts regarding the proxy-s will be shown.

In comparison to the validation of indicators, the results of the mean are lower in the case of proxy-s. Nevertheless, as it can be seen the majority of the proxy-s have obtained a mean superior to 3,50. The proxy-s with a better mark are the "Degree of emotional wellbeing of the stakeholders as a result of the club's activity", "Discount in € applied to tickets", "Value in $€$ of the donation of sporting material", "Price not charged to those children in difficult situations for playing in the club's basketball school" and "Quantity paid in grants to each player". 
In the case of the "Discount in $€$ applied to tickets", R8 thought that "the cost of this initiative can be assumed by the club". Concerning the "Value in $€$ of the donation of sporting material", R1 points out that "this is a good proxy, but be careful with the measurement." Regarding the "quantity paid in grants to each player", in the opinion of R8, clubs "should adopt grants as a common practice." Concerning the "Price not charged to those children in difficult situations for playing in the club's basketball school", R8 thinks that "this discount would greatly benefit those children in trouble."

Those proxy-s that have obtained a mean between 3,00 and 3,50 are the "Average salary per hour of players" and the "Price that would be charged by the clubs for sending their players to these social associations if the activities had a commercial purpose instead (like the advertisement of a product)". In the first proxy, R6 added that "the cost per hour of a player is difficult to calculate. The value of playing a match in a competition is bigger than the value of training." Concerning the second proxy, R4 answered that "I don't know if the price exists and I doubt if it would be adequate to consider it."

In the case of the "Price that would be charged by the clubs for sending their players to these social associations if the activities had a commercial purpose instead (like the advertisement of a product)", two of the experts proposed as proxy-s the usage of "a market price for participating in commercial events" in the case of R6 and "the market price for sending a player to a commercial event" in the case of R3. Hence, we will keep the proxy identified. Concerning the proxy of the "Average salary per hour of players", we agree with the fact that the time that players spend playing the matches is more valuable for the club than their time in the social engagements of the club. Hence, we will eliminate this proxy and the corresponding indicator.

Finally, the proxy that gets a mean below the minimum threshold of 3,00 is the one of "Quantity in € paid per match by the club during the season to the volunteers". The experts have their objections especially because "the point of being a volunteer is that you do not get any compensation" according to R13. The alternative proposed by R6 argues that "the value should refer to the cost per hour of hiring an employee by the club". R6 explains that "it makes sense to consider the proxy of the market value instead of the payment that the club can make". Hence, we will take into consideration this alternative proposed by the experts, and hence establish as a proxy the minimum salary established by the Spanish Government in the year 2018.

\section{Conclusions}

The main conclusion of this chapter is that a methodology of social accounting can be applied and implemented into elite basketball clubs, a kind of organization that shows important peculiarities in comparison to other businesses. In this regard, the fact that European basketball clubs are generally considered as social institutions with a strong stakeholder orientation, determining their ethos and value creation system to their stakeholders, can make these organizations particularly ripe for the application of a social accounting methodology as SPOLY. 
An effort of adaptation and validation of the SPOLY Methodology has been made throughout the process. Starting from the identification of different specific social value variables, on the basis of different social value activities and their corresponding social value dimensions, we go on to identify the different specific social value outputs and proxy-s that will allow the monetization of specific social value. All the outputs and proxy-s identified have been validated by 13 experts from the sports management discipline, both academics and practitioners. This aspect makes the findings of this paper more robust and meaningful for both the academia and the management of elite basketball clubs.

The measurement of social value creation by an elite sport club will give the board a new and useful management tool. In non-profit organizations like sport clubs, it is necessary to evaluate the activity of these organizations according to their capacity to create value to different stakeholders. The knowledge and measurement of the distinct social value dimensions that a basketball club creates to its variety of stakeholders, like communities and social agents, customers and users, public administrations, the media, suppliers, employees and sporting competitions, apart from shareholders, will represent the first step to improve the management of these organizations. These results open an encouraging path towards the disclosure by these organizations of other kind of information that complements their financial statements, so that the running of these organizations can be evaluated from a broader perspective.

At the same time, the results will be useful for public administrations when making a decision about whether or not back a sport club in their jurisdiction. The capacity of these organizations to create a social value to their stakeholders can justify the awarding of public funds to these organizations, provided that they create a bigger social value to their stakeholders.

\section{References}

AGHA, N. \& TAKS, M. (2018): “Modeling Resident Spending Behavior During Sport Events: Do Residents Contribute to Economic Impact?", Journal of Sport Management, 32(5), 473-485, DOI: $10.1123 /$ jsm.2017-0207.

ANDREFF, W. (2011): "Some comparative economics of the organization of sports: Competition and regulation in north American vs. European professional team sports leagues", European Journal of Comparative Economics (EJCE), 8(1), 3-27. http://ejce.liuc.it/18242979201101/182429792011080101.pdf

BABIAK, K. \& WOLFE, R. (2009): "Determinants of Corporate Social Responsibility in Professional Sport: Internal and External Sports", Journal of Sports Management, 23(6), 717-742. DOI: $10.1123 /$ jsm.23.6.717.

BARAJAS ALONSO, Á.A. (2004): Modelo de valoración de clubes de fútbol basado en los factores clave de su negocio, Tesi doctoral, Universidad de Navarra, Munich Personal RePEc Archive (MPRA), https://mpra.ub.uni-muenchen.de/13158/ 
BARAJAS ALONSO, Á.A. \& RODRÍGUEZ GUERRERO, P. (2009): "Situación Financiera del Fútbol Profesional: crisis y ley concursal", Revista Aranzadi de derecho de deporte y entretenimiento, 27, 67-85.

BISCAIA, R., ROSS, S., YOSHIDA, M., CORREIA, A., ROSADO, A. \& MARÔCO, J. (2016): "Investigating the role of fan club membership on perceptions of team brand equity in football", Sport Management Review, 19(2), 157-170. D0I: 10.1016/j.smr.2015.02.001

BROWN, A., MCGEE, F., BROWN, M., \& ASHTON, A. (2010): The Social and Community Value of Football. The Final Report, Supporters Direct, London.

CHAVES ÁVILA, R. (2017): "El tercer sector deportivo", En: Chaves Ávila, R. \& Zimmer, A. (Coords.), El tercer sector en España y en Europa: crisis, barreras en su desarrollo y estrategias de resiliencia en los sectores de la acción social, la cultura y el deporte, 63-78. Universitat de València, Servei de Publicacions, València.

COATES, D., NAIDENOVA, I. \& PARSHAKOV, P. (2017): “Determinants of Russian Football Club Brands", International Journal of Sport Finance (IJSF), 12(4), 321-341.

COATES, D. \& SZYMANSKI, S. (2015): Willingness to pay to host the Summer Olympic Games, Working Paper, University of Maryland Baltimore County, Maryland.

CONN, D. (1997): The Football Business - Fair Game in the '90s?, Mainstream Publishing, Edinburgh.

CONSEJO SUPERIOR DE DEPORTES (2019): Balance de la situación económico-financiera del baloncesto español 1999/2018, Subdirección General de Deporte Profesional y Control Financiero - Ministerio de Cultura y Deporte, Madrid.

DRAUCKER, C.B., MARTSOLF, D.S., ROSS, R. \& RUSK, T.B. (2007): “Theoretical sampling and category development in grounded theory", Qualitative health research, 17(8), 1137-1148. DOI: $10.1177 / 1049732307308450$.

FAIZ, K. (2016): Usability and Accessibility of Impact Assessment for Social Enterprises: System, Purpose, challenges, OCAD University, Toronto. http://openresearch.ocadu.ca/id/eprint/1440.

GIULIANOTTI, R. (2005): "Sport spectators and the social consequences of commodification: Critical perspectives from Scottish football", Journal of Sport and Social Issues (JSSI), 29(4), 386-410. DOI: $10.1177 / 0193723505280530$.

GRAY, R. (2001): "Thirty years of social accounting, reporting and auditing: what (if anything) have we learnt?", Business ethics: A European review, 10(1), 9-15.

DOI: $10.1111 / 1467-8608.00207$. 
GRAY, R., BEBBINGTON, J. \& MCPHAIL, K. (1994): "Teaching ethics in accounting and the ethics of accounting teaching: educating for immorality and a possible case for social and environmental accounting education", Accounting Education, 3(1), 51-75. D0I: 10.1080/09639289400000005.

GREENWOOD, M. \& KAMOCHE, K. (2013): "Social accounting as stakeholder knowledge appropriation", Journal of Management \& Governance, 17(3), 723-743.

DOI: 10.1007/s10997-011-9208-z.

GRIECO, C., MICHELINI, L. \& IASEVOLI, G. (2014): "Measuring Value Creation in Social Enterprises: A Cluster Analysis of Social Impact Assessment Models", Nonprofit and Voluntary Sector Quarterly (NVSQ), 44(6), 1173-1193. DOI: 10.1177/0899764014555986.

HARRISON, J.S., BOSSE, D.A. \& PHILLIPS, R.A. (2010): "Managing for stakeholders, stakeholder utility functions, and competitive advantage", Strategic Management Journal, 31(1), 58-74. DOI: $10.1002 / \mathrm{smj} .801$.

HOLT, M. (2009): "UEFA, governance and the control of club competition in European football”, Birbeck Sport Business Centre research papers, 2(1).

KESENNE, S. (2000): "Revenue sharing and competitive balance in professional team sports", Journal of Sports Economics (JSE), 1(1), 56-65. DOI: 10.1177/152700250000100105.

KING, A. (1997): "New directors, customers, and fans: The transformation of English football in the 1990s", Sociology of Sport Journal, 14(3), 224-240. D0I: 10.1123/ssj.14.3.224.

KUNKEL, T., DOYLE, J.P. \& BERLIN, A. (2017): “Consumers' perceived value of sport team games-A multidimensional approach", Journal of Sport Management, 31(1), 80-95.

DOI: $10.1123 /$ jsm.2016-0044.

LAZKANO DE ANTA, L. \& SAN-JOSE RUIZ DE AGUIRRE, L. (2020): "Monetización del valor social: el caso Clade", Gizarte Ekonomiaren Euskal Aldizkaria/Revista Vasca de Economía Social, 16, 103-127. DOI: 10.1387/reves.20903.

LIU, D. (2016): "Social impact of major sports events perceived by host community", International Journal of Sports Marketing and Sponsorship, 17(1), 78-91.

DOI: 10.1108/IJSMS-02-2016-005.

MARTÍNEZ-LEMOS, R.I. (2015): "Sociedades anónimas deportivas de la liga de fútbol profesional en España: un análisis empresarial descriptivo", Revista Española de Educación Física y Deportes (REEFD), 408, 39-55. https://www.reefd.es/index.php/reefd/article/view/76.

MATHEWS, M.R. (1997): “Twenty-five years of social and environmental accounting research: Is there a silver jubilee to celebrate?", Accounting, Auditing \& Accountability Journal, 10(4), 481-531. DOI: 10.1108/EUM0000000004417. 
MENDIZABAL, X., SAN-JOSE, L. \& GARCÍA-MERINO, J.D. (2020): “Understanding and mapping stakeholders of sport clubs: particularities", Sport, Business and Management: An International Journal, 10(3), 359-378. DOI: 10.1108/SBM-04-2019-0029.

MORROW, S. (2000): "Football clubs on the Stock Exchange: an inappropriate match? The case of Celtic plc.", Irish Accounting Review (IAR), 7(2), 61-90. http://hdl.handle.net/1893/24222.

MORROW, S. (2013): “Football club financial reporting: time for a new model?", Sport, Business and Management: An International Journal, 3(4), 297-311. D0I: 10.1108/SBM-06-2013-0014.

NICHOLLS, A. (2009): “'We do good things, don't we?': 'blended value accounting' in social entrepreneurship", Accounting, Organizations and Society, 34(6-7), 755-769.

D0I: $10.1016 /$ j.aos.2009.04.008.

OLSEN, S. \& GALIMIDI, B. (2008): Catalog of approaches to impact measurement: assessing social impact in private ventures, The Rockefeller Foundation, New York.

PALINKAS, L.A., HORWITZ, S.M., GREEN, C.A., WISDOM, J.P., DUAN, N. \& HOAGWOOD, K. (2015): "Purposeful sampling for qualitative data collection and analysis in mixed method implementation research", Administration and Policy in Mental Health and Mental Health Services Research, 42(5), 533-544. D0I: 10.1007/s10488-013-0528-y.

PUJOL PINTO, A. (2019): Anàlisi de tres clubs de bàsquet, [Treball de Fi de Grau, Universitat de Barcelona. Dipòsit digital de la Universitat de Barcelona. http://hdl.handle.net/2445/139219.

RASCHE, A. \& ESSER, D.E. (2006): "From stakeholder management to stakeholder accountability", Journal of Business Ethics (JBE), 65(3), 251-267. D0I: 10.1007/s10551-005-5355-y.

RETOLAZA ÁVALOS, J.L., SAN-JOSE RUIZ DE AGUIRRE, L. \& RUIZ-ROQUEÑI, M. (2015): “Monetarizing the social value: theory and evidence", CIRIEC-España, Revista de Economía Pública, Social y Cooperativa, 83, 43-62. https://ojs.uv.es/index.php/ciriecespana/article/view/13418.

SALTUK, Y., IDRISSI, A., BOURI, A., MUDALIAR, A. \& SCHIFF, H. (2014): Spotlight on the market: The impact investor survey, J.P. Morgan \& Global Impact Investing Network, London.

SMITH, A.C.T. \& WESTERBEEK, H.M. (2007): "Sport as a Vehicle for Deploying Corporate Social Responsibility", The Journal of Corporate Citizenship (JCC), 25, 47-48. https://www.jstor.org/stable/jcorpciti.issue-25.

SMITH, J.A. \& OSBORN, M. (2003): “Interpretative phenomenological analysis", En: Smith, J.A. (Ed.), Qualitative psychology: A practical guide to research methods, 53-80. Sage Publications, Inc., London. 


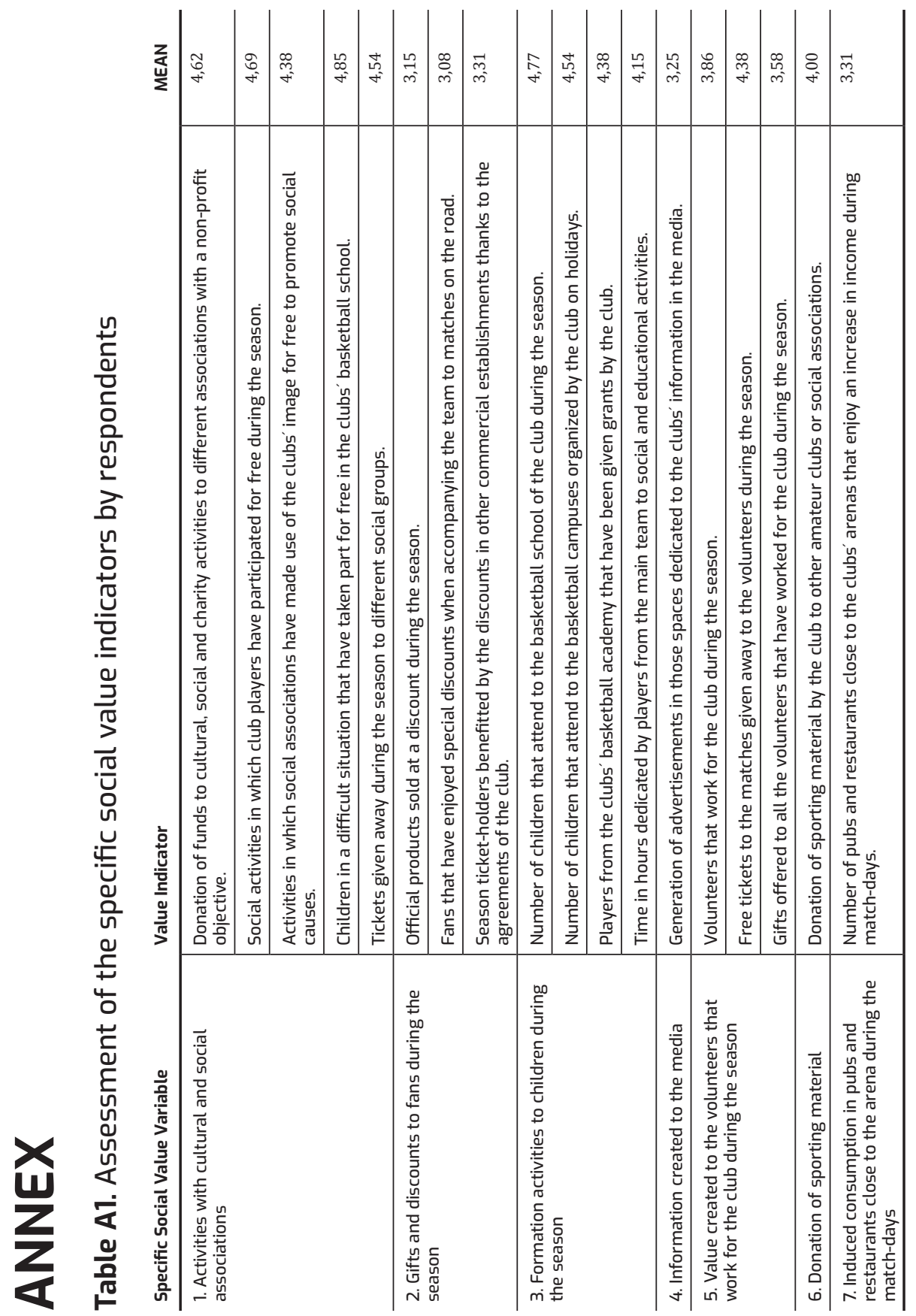




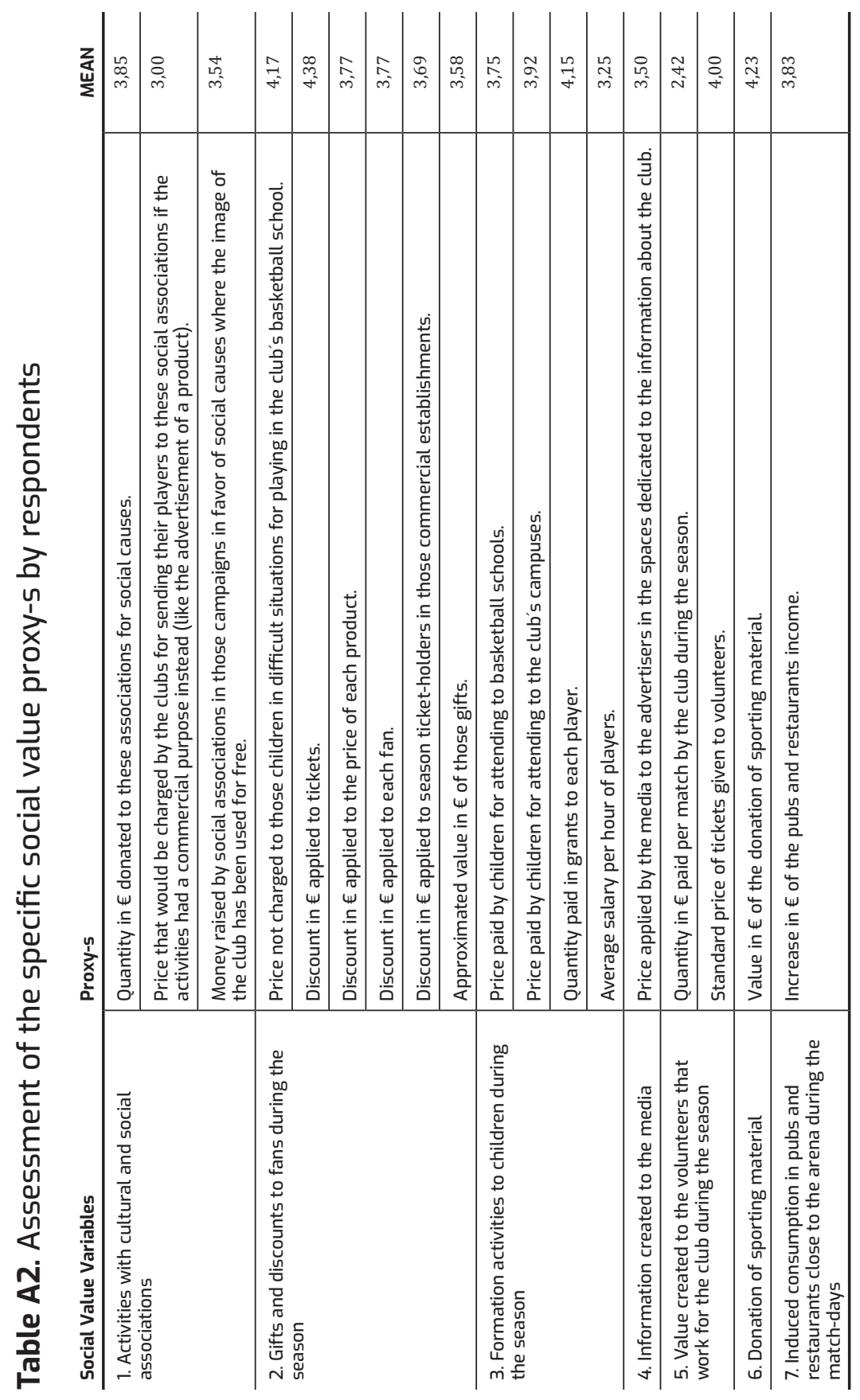


